\title{
MARCAS DA HISTÓRIA
}

\section{Hellen do Socorro Lameira de Goes ${ }^{1}$}

Resumo: O presente texto trata do memorial sobre a trajetória escolar de Hellen do Socorro Lameira de Goes, ex-integrante do Programa Conexões de Saberes. Tem como objetivo apresentar os passos percorridos desde o início da educação básica até a entrada à UFPA e quais os principais entraves de estudantes das comunidades populares adentrarem o ensino superior público. A memória foi usada como principal referência para construção do material. Em seus resultados, apresenta os esforços individual e coletivo para que de fato a educação seja uma questão de direito e não de privilégio de poucos.

Nasci no dia 07 de outubro de 1985, às 2 h da manhã, na cidade de Belém. Esse acontecimento representou tristeza para muitos e alegria para uma pessoa apenas, minha mãe. Meu nascimento se deu em um momento conturbado da minha família; fui produto de uma relação na qual não existia amor apenas atração, mas vou começar contar essa história do início a fim de que seja entendida por todos os leitores.

\section{Meu nascimento}

Enquanto minha mãe estava grávida de mim, morava em um interior chamado Tatuaia e já tinha duas filhas de um relacionamento que não deu certo por questões familiares. Todos naquele lugar comentavam sobre o assunto, principalmente porque o homem que engravidou minha mãe já tinha uma família formada e era muito conhecido.

Chegou o grande dia em que minha mãe sentiu as dores do parto; foi no dia 06 para o hospital e às 2:00h da madrugada de 07 de outubro de 1985 ouviu-se o choro desesperado de uma menina que acabara de nascer, saudável, mas com muita fome. Era eu.

Nasci, e a notícia correu como um relâmpago por todo lugar, inclusive pelo interior onde estavam os filhos e os parentes do meu pai; todos estavam ansiosos para saber se era menino ou menina, se nasceu com deficiência ou não, quantos quilos havia pesado, mas, principalmente, se parecia com o pai ou não. Minha mãe pediu muito a Deus para que eu não parecesse nenhum pouco com os parentes do meu pai, mas quando viu meu rosto não teve

\footnotetext{
${ }^{1}$ Acadêmica* do curso de Letras - UFPA/Castanhal, e-mail: hellenngoes@yahoo.com.br

* atualizado pela última vez em 2008
}

Revista PET Interdisciplinar e Programa Conexões /UFPA On-line. Ed. Especial - 2017, BELÉM/ PA - ISSN 2447-097X 
como esconder, pois tinha todos os traços dele. Mas quem me registrou como filha foi o militar, pai de minhas primeiras irmãs.

Minha mãe ainda ficou algum tempo na cidade de Belém, pois as pessoas com quem estava convivendo não queriam deixá-la voltar para o interior, mas acabou voltando para a casa de seus pais, e chegando lá foi para a lida de sempre: trabalhar na roça para sobreviver, agora com mais responsabilidade, pois tinha três bocas para sustentar em tudo. Minha avó correu atrás de meu pai a fim de que ele ajudasse a me manter, e ele de vez em quando dava uma lata de leite para minha mãe, apenas isso.

O tempo se passou e quando eu já tinha 02 anos, minha mãe conheceu outro homem, namorou ele, fato que minha avó não aceitava, e por causa disso eles fugiram. Minha mãe conversou direito com ele, disse que já tinha três filhas e para ficar com um novo companheiro, ele deveria assumir também suas filhas, fato que ele não ignorou e afirmou com a seguinte frase interiorana: Ah! Então vamos! Quem quer a vaca, quer os bezerros também. Depois de terem fugido, no dia seguinte foram na casa de meus avós buscar as crianças e o resto da bagagem. Como não havia muita coisa para levar, saíram de lá duas meninas e uma trouxa de roupa (digo duas meninas porque meu avô tinha pedido uma das gêmeas para minha mãe, já que houve um tempo em que a Gisele ficou muito doente, e meu avô pediu pra Deus que se Ele a curasse, ele a criaria como filha).

Minha mãe foi embora para o outro lado do interior comigo, minha irmã Jucilene e aquele homem, que seria agora nosso novo pai. Havia uma casa para todos nós, e com o tempo foram comprados os móveis. Ele também casou com minha mãe no civil e religioso. Após 02 anos de relacionamento, minha mãe engravidou e teve mais uma menina, chamada Leidiane; no ano seguinte teve mais uma, a Regiane.

Nossos pais sempre zelaram pela boa educação dos filhos, apesar de não haver escola naquele lugar, o aprendizado ocorria em casa, através dos conselhos e ensinamentos que eles nos repassavam. Minha mãe foi a mais preocupada com a nossa vida escolar; como não tinha material nem escola, ela nos ensinava o que aprendeu escrevendo com um pedaço de pau no chão do quintal de nossa casa. Assim, com ela aprendi todo o alfabeto e os cálculos matemáticos.

Meu pai sempre garantiu o sustento da casa, minha mãe o ajudava no trabalho duro da roça, ele nunca nos impôs esse trabalho; eu como era a responsável pelas outras, até pela mais velha que era deficiente, ficava em casa fazendo comida, lavando louça, varrendo casa e cuidando das meninas.

Revista PET Interdisciplinar e Programa Conexões /UFPA On-line. Ed. Especial - 2017, BELÉM/ PA - ISSN 2447-097X 
Minha família era bastante equilibrada, graças a Deus meus pais viviam em harmonia e em concordância. Apesar disso, meu pai resolveu mudar de lugar, com o objetivo de alcançar melhoras para a família; foi primeiro procurar uma casa para comprar em uma cidade pequena conhecida como Bujaru, localizada a $70 \mathrm{~km}$ de Belém. Em 1992 fomos com toda nossa bagagem para o nosso novo lugar.

Chegando lá, percebemos logo os olhares daquele povo desconfiado, mas com o tempo nos acostumamos, nossa casa era de madeira, e meu pai deu um jeito de colocar uma venda de carvão e farinha, produtos que ele conseguia quase de graça do interior onde morávamos. Minha mãe se preocupou logo em arrumar uma escola para eu estudar, pois já estava com 07 anos e não tinha freqüentado nenhuma. No momento em que cheguei à escola, os professores e diretores se surpreenderam com o grau de ensino que já possuía, mesmo que ainda não tivesse freqüentado a sala de aula, por isso resolveram logo me passar no meio do ano para a série seguinte, pois diziam que eu já estava bastante adiantada e não poderia ficar naquela série senão me atrasaria muito.

Agradeço muito à minha mãe por ter me ensinado o que ela tinha aprendido, mesmo que fosse pouco, mas serviu e muito para o bom andamento dos meus estudos, agradeço também aos professores que souberam reconhecer a minha capacidade e apostaram nela, me dando uma chance para prosseguir.

Sempre procurei ser uma boa aluna e a melhor em tudo o que fazia, por isso era criativa nos trabalhos e às vezes até surpreendia os professores. A partir do momento que comecei estudar, sentia vontade de dar aulas, e o fazia nas brincadeiras com minhas irmãs, eu era a professora e elas eram as alunas; enquanto elas não estudavam, eu fazia o mesmo que minha mãe fazia antes quando morávamos no interior. Eu observava bem as formas que os professores usavam na sala de aula e tentava fazer o mesmo em casa com minhas alunas.

Desde criança dizia para minha mãe que eu seria professora e o sonho continua, estou lutando para isso. Sempre me esforcei em tudo, nunca repeti nenhuma série e participava de todas as atividades da escola; até hoje não consigo esquecer as brincadeiras de pescaria, das festas juninas e dos eventos promovidos pela escola.

Com o passar do tempo, meu pai foi aumentando o comércio em casa vendendo outras mercadorias, com o lucro das vendas foi juntando dinheiro para construir uma casa de alvenaria. Em 1997, conseguimos mudar para a casa nova; os negócios do meu pai iam de vento em popa, apesar disso, o ensino dado aos filhos não mudava: agradeço a meus pais, pois foram a base de tudo para que eu fosse uma pessoa equilibrada. Nunca esqueço que, depois do

Revista PET Interdisciplinar e Programa Conexões /UFPA On-line. Ed. Especial - 2017, BELÉM/ PA - ISSN 2447-097X 
almoço, pelo menos duas vezes na semana, meu pai conversava com as filhas e dava conselhos, fazíamos orações juntos, e se tivesse que puxar a orelha de alguém, aquele era o momento certo. Papai não permitia que fôssemos às festas e dificilmente freqüentávamos aniversários, saíamos apenas para ir à igreja, à escola e a outras programações feitas em família. O horário de dormir todo dia era às 20:00h; recordo-me que quando chegava esse horário, papai dizia meninas, já são 8:00h, logo todas as filhas iam procurar cama ou rede, pediam a bênção dele e da mamãe e iam dormir. Filmes e novelas nem pensar! E eram difíceis as exceções.

Antes eu não entendia porque meu pai agia daquela forma, ficava revoltada, pois todas as minhas colegas saiam à noite para ir à praça, às festas, assistiam televisão e iam à casa do vizinho, porém e eu e minhas irmãs não podíamos fazer nada disso. Agradeço muito pela base de ensino que recebi, pois meus pais sabiam muito bem o que era melhor para seus filhos.

A minha família era muito feliz, não tinha do que se queixar, até que chegou um tempo em que prosperamos bastante através do comércio que ia aumentando e, por causa disso, meu pai ficou bem conhecido na cidade, fez muitas amizades, mas o pior de tudo foi que ele começou a beber com os amigos, o que provocou um desequilíbrio familiar. Papai começou beber em outros bares, pagava todas, até que começou beber com os amigos no seu próprio estabelecimento, causando a perda de boa parte do lucro, pois os amigos não pagavam nada. Além da bebida, ele também começou a ter relacionamentos fora do casamento com várias mulheres, minha mãe ficava em casa e só sabia pela boca dos outros que as mulheres, em outros bairros, estavam brigando por causa dele.

A situação ficou tão crítica que a felicidade que tínhamos em casa se foi. Depois de 14 anos de casamento, meus pais começaram a brigar constantemente por causa do desperdício de meu pai, e as discussões só faziam a situação piorar. Minha mãe começou a afogar suas lágrimas em copos de cerveja, e lembro-me que várias vezes os amigos iam beber em casa e meus pais os acompanhavam, eu era quem cuidava do comércio; no final de tudo restavam apenas meus pais bebidos e muitas cervejas não pagas.

Neste contexto, a prosperidade que tínhamos alcançado também se despediu e foi embora. As dívidas foram aumentando e chegou o momento em que meu pai não tinha um centavo para pagar contas que ele não sabia explicar; as mercadorias foram acabando e não havia dinheiro para comprar outras. A solução encontrada para quitar as dívidas foi dar em troca o que tínhamos dentro de casa, com som, refrigerador... Fico triste e emocionada por lembrar esse momento tão difícil que passamos, fico a me perguntar como que meu pai 
permitiu que isso acontecesse. Por que ele se exaltou com o que tinha conquistado e esqueceu da nossa família?!

Esse foi o momento mais crítico da nossa história, pois por pouco não passamos fome. Estávamos acostumados com a vida boa que tínhamos: na hora em que queríamos pão, refrigerante, bombons, biscoitos ou outra coisa qualquer, bastava ir ao comércio e pegar, mas agora até para encontrar um ovo era difícil. Existia um senhor que sempre estava em casa e gostava muito de toda a família, era ele que saia para outro comércio mais próximo e comprava alguns ovos para comermos naquele dia.

Melhor é um bocado seco e com ele a tranqüilidade do que a casa cheia de vítimas, com contenda (SL 17,1)

Agradeço muito a Deus por não ter nos deixado passar fome, nesse tempo doeu um pouco a barriga, mas Deus não nos deixou desamparados. Perdemos praticamente tudo e, principalmente, a estrutura familiar, meu pai já não era o mesmo e minha mãe sofria demais com aquela situação.

Nesse período, terminei o ensino fundamental e com muitas expectativas entrei no ensino médio, mas cursei somente até o meio do ano, pois por causa de uma discussão meu pai mandou que minha irmã mais velha fosse embora, logo minha mãe também disse que iria, já que não deixaria sua filha sozinha no mundo. Então foram as duas embora, e eu fiquei com minhas duas irmãs mais novas para terminarmos o estudo até ficarmos de férias no meio do ano; em uma conversa com nossos pais decidimos que iríamos com a mamãe. Foi um momento decisivo na vida familiar, eu não compreendia ainda a profundidade desse acontecimento, que resultados iriam aparecer mais tarde; eu encontrava meus vizinhos e falava contente para todos que iria embora daquela cidadezinha para outra maior, a famosa cidade-modelo: Castanhal.

Minha mãe conversou com minha avó, que havia construído uma casa em Castanhal e estava passando o maior tempo lá, e ela nos deu permissão para morarmos debaixo do mesmo teto. Então, mamãe foi logo embora com minha irmã e eu fiquei com as meninas. Chegado o tempo certo, 30 de junho, fomos encontrá-las, todas felizes porque iríamos para uma cidade diferente. Foi uma alegria quando chegamos, na casa de minha avó tinha bastante gente, conheci os parentes que não conhecia, e a cidade grande que me empolgou bastante, pois onde morávamos nem sinal de trânsito tinha. Eu ficava admirada com os grandes prédios, com a 
quantidade de carros e lojas e, principalmente, com a diversidade de pessoas que moravam naquele lugar, que agora seria meu também.

No começo da convivência foi uma maravilha, somente rosas, mas com o passar do tempo e o costume, os espinhos também foram aparecendo. Começamos a passar dificuldades, pois a outra realidade era que minha mãe teria que sustentar quatro filhas, sozinha, e o dinheiro que tinha não era suficiente. O papai ainda veio umas quatro vezes atrás dela, implorar para voltar, mas ela estava com tanto ódio que em todas as vezes disse $N \tilde{A} O$; ele não ajudava em nada; minha mãe tinha que dar um jeito na situação. O que ajudava era a pensão que ela recebia do primeiro marido, o militar que também me registrou como filha, e um salário mínimo pelo benefício de minha irmã deficiente; mamãe também nunca conseguiu um trabalho por causa do pouco estudo que possuía, por isso algumas vezes foi obrigada a voltar para o interior, onde havia morado, a fim de fazer alguns sacos de farinha para vender e ganhar um dinheiro extra para ajudar no sustento da casa.

\section{Os sonhos}

Desde criança sempre fui uma menina sonhadora. Sonhava acordada, imaginava minha vida quando estivesse adulta, construía meus próprios sonhos e fantasias. E naquele momento, por mais que a situação estivesse difícil, continuava sonhando.

Quando chegamos a Castanhal, minha mãe procurou logo os colégios onde eu e minhas irmãs poderíamos concluir os estudos. Fiquei na escola Lameira Bittencourt, para cursar o restante do $1^{\circ}$ ano; decidi que iria estudar muito para um dia conseguir oferecer uma vida mais digna para minha mãe, pois ela era a única razão do meu viver naquele momento. Falo assim porque chegou um tempo em que achamos que ninguém se importava conosco e eu senti uma angústia tão grande por ver a minha mãe sempre sofrendo, sem ser valorizada. Minha vontade era viver em função dela, para o bem-estar dela, e um dia conseguir vê-la sorrindo para o resto da vida, sem sofrimento. Nesse momento eu sonhava mais e dizia para minha mãe: não se preocupe, pois um dia nós conquistaremos tudo que quisermos.

Ao completar 16 anos, minha mãe me levou para conhecer meu pai biológico, pois o único contato que tive com ele foi quando ainda era muito criança, e já não me lembrava mais do rosto daquele homem. Conversamos, e minha mãe disse a ele que deveria me sustentar, pois ela já tinha feito muito por mim. Ele imediatamente concordou e a partir daquele 
momento, toda quinzena do mês me dava uma quantia para o que precisasse; fiquei muito feliz porque aquele dinheiro ajudava minha mãe no sustento da família.

Decidi, então, que faria vestibular, só não sabia a área, mas tive a certeza que entraria na faculdade, apesar de não ter na família materna ninguém que já tivesse conquistado algo parecido. Quando já estava no $3^{\circ}$ ano, meu pai pagou um cursinho para mim, e eu estudava pela manhã e pela tarde, às vezes até à noite, tudo com a intenção de passar no vestibular. Mas surgiram tantas fofocas e falsas afirmações sobre mim, que minha mãe disse que era melhor parar o cursinho. Pedi a ela que apenas confiasse em mim e não desse ouvido para o que os outros falavam, pois ninguém sabia de minha vida. Ela concordou e continuei fazendo o cursinho.

Nesse tempo fizeram um loteamento próximo de onde morávamos e minha mãe comprou um lote, foi uma oportunidade única, pois o valor era bem acessível. Não demorou muito para que ela pedisse ao meu tio, que é pedreiro, que começasse a levantar dois compartimentos para ela; foi assim que começamos a construir nossa casa própria. Antes do final do ano já estávamos debaixo de nosso teto, onde poderíamos gritar, cantar, falar, pois éramos as rainhas do lar, nesse nós mandávamos.

Nesse ínterim, me dediquei mais do que devia, tanto que perdia até o apetite, comecei emagrecer muito, sentia fortes dores de cabeça e estudava sem parar. .Achei melhor não me sacrificar tanto; resolvi confiar mais em Deus.

No final do ano, fui aprovada e conclui o ensino médio. Fui fazer as provas do vestibular tanto da UEPA quanto da UFPA, para o curso de Letras, uma para Iguarapé-Açu e a outra para Castanhal. Foi uma festa só, consegui ser aprovada nas duas universidades, e tive a oportunidade de escolher em qual queria estudar... Foi um privilégio para mim e, principalmente, para minha mãe, poder mostrar aos outros que eu não era o que eles pensavam, mas sim o que eu queria ser.

É lógico que optei por estudar na UFPA, pois há campus na cidade onde moro, o que evitaria gastos com deslocamento e estadia. Comecei a estudar e a planejar o meu futuro e o da minha família. Logo que entrei na universidade consegui uma bolsa-trabalho, que contribuiu para me manter e ajudar minha mãe em casa. Os sonhos não acabaram, eles continuam vivos.

Revista PET Interdisciplinar e Programa Conexões /UFPA On-line. Ed. Especial - 2017, BELÉM/ PA - ISSN 2447-097X 


\section{O presente}

Depois de tantas dificuldades que enfrentei na minha vida, consigo enxergar e aceitar cada situação, pois compreendo que sem luta não há vitória. Se tivesse desistido no primeiro momento, não estaria hoje escrevendo minha experiência de vida, a qual alguém, um dia, possa até se identificar.

O que quero dizer é que o segredo da vitória é a persistência. Então, não devemos nunca desistir de nossos ideais, porque se não sou capaz de pelo menos tentar conquistar meus sonhos, a vida passa, as pessoas passam e o tempo se vai, e quando se percebe, não há mais oportunidades. Por isso é importante não perder o alvo da nossa vida e ir em busca dele, quebrando todos os obstáculos. Só assim será possível cantar vitória depois. 